\title{
Lingual Osseous Choristoma: A Case Report and Review of the Literature
}

\section{Ozlem Saraydaroglu, Selin Narter, Mine Ozsen}

${ }^{1}$ Department of Surgical Pathology, Uludag University, Faculty of Medicine, Bursa, Turkey.

\begin{abstract}
Introduction: Osseous choristoma is a benign lesion that is characterized by proliferation of mature osseous tissue in an abnormal anatomical location. The lesion, which was first described by Monserrat in 1913 as "lingual osteoma" has been called "osseous choristoma" since 1971. Here, we present a rare case of osseous choristoma located on the tongue and a review of the literature. Case Report: A 26 year-old male patient was referred to the Department of ENT with the complaint of swelling of the tongue. Physical examination showed a nodular, sessile lesion on the base of the tongue and the lesion was removed. Histopathological examination of the material revealed a well-defined, submucosal lesion consisting of mature bone tissue and was reported as "osseous choristoma". Conclusion: Osseous choristoma is a benign lesion that occurs mostly in women in their second or third decades of life, although it can be seen in a wide age range. Osseous choristoma may occur in different locations of the oral cavity and maxillofacial region such as the tongue, buccal mucosa, alveolar mucosa, submandibular region, submental region, masseter muscle and palate. This rare entity should be kept in mind because it may be confused with other benign lesions of the tongue like hemangioma, lymphangioma, hamartoma and malignant tumors.
\end{abstract}

Keywords: Koristom- Lingual- Oral- Osseous- Dil

Asian Pac J Cancer Care, 4 (4), 145-149

\section{Introduction}

Choristoma is defined as the proliferation of normal tissue in an abnormal anatomical location. Although choristomas are usually asymptomatic, it is important they recognize them as they may clinically mimic neoplasms when they give symptoms. Choristomas located in the oral cavity may consist of various tissues such as bone, cartilage, glial tissue, gastric mucosa and sebaceous glands [1].

Osseous choristoma is a benign lesion that develops with the proliferation of mature bone tissue in an abnormal region in which bone tissue is not normally found. This entity was first defined in 1913 by Monserrat as "lingual osteoma". The term "osseous choristoma" was used by Krolls et al. in 1971 for the first time [2-3].

\section{Case Report}

A 26-year-old male patient was referred to the XXX Department of Otolaryngology in May 2018 with the
Submission Date: 04/01/2019 Acceptance Date: 07/15/2019

complaint of swelling on his tongue.

Physical examination revealed a nodular lesion at the tongue base and endoscopy was planned. The endoscopic study showed a sessile, nodular lesion that was located on the midline of the posterior region of the tongue. It was considered to be hypertrophy of the circumvallate papilla. Medical treatment and follow-up were recommended. After one month, no regression was seen and the patient underwent excisional biopsy.

The surgical specimen was $0,6 \times 0,5 \times 0,3 \mathrm{~cm}$ sized, gray-white, firm nodular lesion. The entire material was sampled after decalcification process.

Histopathological examination revealed a submucosal, well-demarcated nodular lesion consisting of osseous tissue beneath non-keratinizing squamous epithelium (Figure 1). The bone tissue showed lamellation with well-developed Haversian system. Osteoblastic, osteoclastic activity, mitosis or cytological atypia was not seen (Figure 2).

The histological findings were consistent with the diagnosis of lingual osseous choristoma. After six

Corresponding Author:

Dr. Ozlem Saraydaroglu

Uludag University, Faculty of Medicine, Department of Surgical Pathology 16059, Gorukle, Bursa, Turkey.

Email: osaraydaroglu@uludag.edu.tr 
Table 1. Review of the Literature

\begin{tabular}{|c|c|c|c|c|c|}
\hline Author/Year & No. of cases & Age/Sex & Symptom & Size $(\mathrm{mm})$ & Localization \\
\hline Present Case & 1 & $26 / \mathrm{M}$ & Lump & 6 & Posterior \\
\hline Yoshimura/2017 ${ }^{10}$ & 1 & $7 / \mathrm{M}$ & None & 6 & Posterior \\
\hline Heinz $/ 2017^{2}$ & 1 & $21 / \mathrm{F}$ & Lump & 5 & Posterior \\
\hline Rezende/2017 ${ }^{13}$ & & $9 / \mathrm{F}$ & None & 3 & Posterior \\
\hline Turan/2016 ${ }^{9}$ & 1 & $41 / \mathrm{F}$ & Lump & 10 & Posterior \\
\hline $\operatorname{Tran} / 2016^{14}$ & 1 & $30 / \mathrm{F}$ & Lump, Gagging & 5 & Posterior \\
\hline \multirow[t]{2}{*}{ Adhikari/2016 ${ }^{12}$} & 2 & $15 / \mathrm{F}$ & Lump & 5 & Posterior \\
\hline & & $21 / \mathrm{F}$ & Pain & 5 & Posterior \\
\hline Davidson/2016 ${ }^{15}$ & 1 & $11 / \mathrm{M}$ & Lump & - & Posterior \\
\hline Ginat/2016 ${ }^{16}$ & 1 & $33 / \mathrm{F}$ & None & - & Posterior \\
\hline Valle $/ 2015^{6}$ & 1 & $21 / \mathrm{F}$ & None & 8 & Posterior \\
\hline Saniasiaya /2015 ${ }^{17}$ & 1 & $25 / \mathrm{F}$ & None & 10 & Posterior \\
\hline Tachasuttirut $/ 2015^{18}$ & 1 & $27 / M$ & None & 9 & Posterior \\
\hline Kaplan/2015 ${ }^{19}$ & 1 & $44 / F$ & - & - & Posterior \\
\hline Stanford $/ 2015^{20}$ & 1 & $11 / \mathrm{M}$ & None & 11 & Posterior \\
\hline Gorini/2014 ${ }^{7}$ & 1 & $10 / \mathrm{F}$ & Lump & 10 & Posterior \\
\hline Yamamoto/2014 ${ }^{8}$ & 1 & $11 / \mathrm{M}$ & Lump & 8 & Posterior \\
\hline $\operatorname{Lin} / 2013^{21}$ & 1 & $15 / \mathrm{M}$ & Lump & 5 & Posterior \\
\hline Chen/2012 22 & 1 & $57 / \mathrm{F}$ & None & 10 & Posterior \\
\hline Toda/2012 ${ }^{23}$ & 1 & $20 / \mathrm{F}$ & - & - & Posterior \\
\hline Kobori/2011 ${ }^{24}$ & 1 & $37 / \mathrm{F}$ & None & 8 & Posterior \\
\hline Hironaka/2010 25 & 1 & $25 / \mathrm{F}$ & None & - & Posterior \\
\hline Naik/2009 26 & 1 & $25 / \mathrm{F}$ & Lump & 12 & Posterior \\
\hline Andressakis/2008 ${ }^{1}$ & 1 & $72 / \mathrm{M}$ & Pain, Lump, Disphagia & 15 & Posterior \\
\hline Hibi/2007 27 & 1 & $32 / \mathrm{F}$ & None & 5 & Posterior \\
\hline Benamer/2007 28 & 1 & $14 / \mathrm{F}$ & Lump, Gagging & 10 & Posterior \\
\hline Velez/2003 29 & 1 & - & - & - & Lateral \\
\hline Horn/2001 30 & 1 & $11 / \mathrm{F}$ & None & - & Posterior \\
\hline Piattelli/2000 31 & 1 & $64 / \mathrm{F}$ & None & 8 & Floor \\
\hline Supiyaphun/2000 ${ }^{32}$ & 3 & - & - & - & Posterior \\
\hline $\mathrm{Kim} / 1999^{33}$ & 1 & $17 / F$ & - & - & Posterior \\
\hline $\operatorname{Lin} / 1998^{4}$ & 1 & $21 / \mathrm{F}$ & Lump & 12 & Posterior \\
\hline \multirow[t]{8}{*}{ Supiyaphun/1998 ${ }^{34}$} & 8 & $28 / \mathrm{F}$ & Irritation & 10 & Posterior \\
\hline & & $25 / \mathrm{F}$ & Lump & 7 & Posterior \\
\hline & & $9 / \mathrm{F}$ & None & 7 & Posterior \\
\hline & & $35 / F$ & None & 7 & Posterior \\
\hline & & $27 / \mathrm{F}$ & None & 12 & Posterior \\
\hline & & $21 / \mathrm{F}$ & Lump & 15 & Posterior \\
\hline & & $22 / \mathrm{M}$ & None & 9 & Posterior \\
\hline & & $19 / \mathrm{F}$ & None & 11 & Posterior \\
\hline \multirow[t]{2}{*}{ Vered/1998 35} & 2 & $44 / \mathrm{M}$ & Gagging, Nausea, Disphagia & 7 & Lateral \\
\hline & & $27 / M$ & Pain, Gagging & 10 & Posterior \\
\hline Horie/1998 36 & 1 & $25 / \mathrm{F}$ & Disphagia & 2 & Posterior \\
\hline Pineau/1997 37 & 1 & - & None & - & - \\
\hline Nakanishi/1996 ${ }^{38}$ & 1 & $7 / \mathrm{F}$ & - & 5 & Posterior \\
\hline Manganaro/1996 ${ }^{39}$ & 1 & - & - & - & - \\
\hline Ngeow/1996 $6^{40}$ & 1 & $23 / \mathrm{F}$ & Lump & 15 & Posterior \\
\hline Takahashi/1995 ${ }^{41}$ & 1 & $9 / \mathrm{F}$ & Lump & 5 & Posterior \\
\hline
\end{tabular}


Table 1 Countinued. Review of the Literature

\begin{tabular}{|c|c|c|c|c|c|}
\hline Author/Year & No. of cases & Age/Sex & Symptom & Size $(\mathrm{mm})$ & Localization \\
\hline Wang/1993 ${ }^{42}$ & 1 & $30 / \mathrm{F}$ & - & - & Posterior \\
\hline Nozoe/1993 ${ }^{43}$ & 1 & $11 / \mathrm{F}$ & - & 8 & Posterior \\
\hline \multirow[t]{2}{*}{ Ishikawa/1993 ${ }^{44}$} & 2 & $53 / \mathrm{F}$ & Lump & 8 & Posterior \\
\hline & & $18 / \mathrm{F}$ & Lump & 9 & Middle \\
\hline Machino/1990 45 & 1 & $14 / \mathrm{F}$ & - & - & Posterior \\
\hline Shintani/1990 ${ }^{46}$ & 1 & $23 / \mathrm{F}$ & - & 8 & Posterior \\
\hline Mizukami/1988 ${ }^{47}$ & 1 & $28 / \mathrm{F}$ & - & 5 & Middle \\
\hline Tohill/1987 ${ }^{11}$ & 1 & $31 / \mathrm{F}$ & None & 7 & Posterior \\
\hline Ioroi/1986 48 & 1 & $14 / F$ & - & - & Posterior \\
\hline Cabbabe $/ 1986^{5}$ & 1 & $5 / \mathrm{F}$ & None & - & Posterior \\
\hline Weitzner /1986 ${ }^{49}$ & 3 & - & None & - & - \\
\hline \multirow[t]{2}{*}{ Shimono/1984 ${ }^{50}$} & 2 & $47 / F$ & Lump & 16 & Posterior \\
\hline & & $37 / F$ & Lump & 15 & Posterior \\
\hline Azuma/1984 ${ }^{51}$ & 1 & $27 / \mathrm{M}$ & None & 10 & Posterior \\
\hline Sheridan /1984 ${ }^{52}$ & 1 & $20 / \mathrm{F}$ & Lump & 10 & Middle \\
\hline \multirow[t]{2}{*}{ McClendon /1975 53} & 2 & $15 / F$ & None & 14 & Posterior \\
\hline & & $20 / \mathrm{M}$ & None & 10 & Posterior \\
\hline \multirow[t]{8}{*}{ Krolls/1971 3} & 8 & $22 / \mathrm{F}$ & None & 7 & Posterior \\
\hline & & $23 / \mathrm{M}$ & - & - & Posterior \\
\hline & & $73 / \mathrm{M}$ & Gagging & - & Posterior \\
\hline & & 9/F & Gagging & - & Posterior \\
\hline & & $25 / \mathrm{F}$ & None & 5 & Posterior \\
\hline & & $11 / \mathrm{F}$ & None & 20 & Posterior \\
\hline & & $23 / \mathrm{M}$ & None & 5 & Middle \\
\hline & & $39 / \mathrm{M}$ & None & 6 & Middle \\
\hline
\end{tabular}

months of follow-up there is no evidence of recurrence.

\section{Discussion}

\section{Discussion and Review of the Literature}

We searched the literature in PUBMED, MEDLINE, Google Scholar and XXXXX Library database using the keywords "lingual", "osseous", "choristoma", "tongue", "lesion" and their combinations. We also examined the content and bibliography of all the available publications manually. Only the cases with the histopathological diagnosis of "lingual osseous choristoma" were included. The diagnosis of "osteoma" were excluded from the review. Our review revealed 77 lingual osseous choristoma cases reported between 1971 - 2017 (Table 1) [1-53].

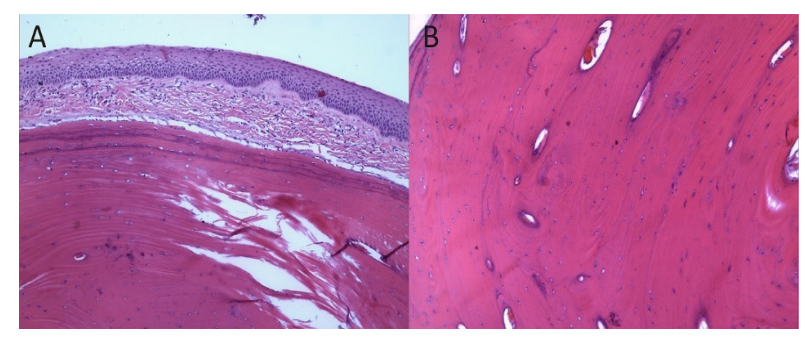

Figure 1. Submucosal Nodular Lesion Consisting Mature Bone (H\&Ex40).
Lingual osseous choristomas can occur at any age but the majority of the patients are in their second or third decades of life [4]. Among the cases reported in the literature, the youngest patient was 5 and the oldest was 73 (mean age: $25,2+14,8$ ) [3-5]. There is a strong female predilection (F/M: 50/17). Our case is a 26-year-old male patient.

Osseous choristomas of the oral cavity and maxillofacial region are most frequently localized in the tongue. $88,2 \%$ of the cases, the lesion was located in the posterior one-third of the tongue, $7,4 \%$ in the middle one-third of the tongue, $2,9 \%$ in tongue lateral borders and $1,5 \%$ on the floor of the tongue. In addition, buccal mucosa, buccal vestibule, alveolar mucosa, submandibular region, submental region, retromolar region, masseter muscle and palate localization can be seen [6].

The etiopathogenesis of lingual osseous choristoma is not fully understood. There are two theories widely recognized to explain the development of osseous choristomas. These are the "embryological" and "post-traumatic" (reactive) theory. According to the embryological theory, the lesion develops from the pluripotent cells in the 1st and 3rd branchial arches. The post-traumatic theory is based on the fact that posterior one-third of the tongue is the most common site of traumatic irritation of the oral cavity. The theory suggests that local inflammation and calcium deposition 


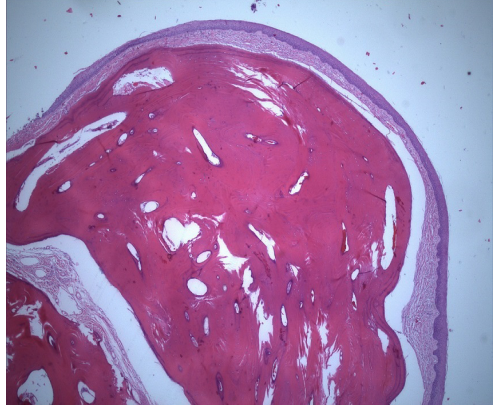

Figure 2. A. Non-keratinizing Squamous Epithelium on the Surface of Osseous Choristoma (H\&Ex200). B. Lamellar mature bone showing no atypia or mitosis (H\&Ex400).

in the trauma site give rise to the lesion [7]. In our case, the lesion consisted of mature bone tissue with fully developed Haversian system and not just calcification. Also, there was no evidence of local inflammation in the surrounding tissue. We believe that post-traumatic theory alone is insufficient to explain the etiopathogenesis of lingual osseous choristoma.

Osseous choristoma of the tongue is mostly asymptomatic (46\%). In symptomatic cases, lump $(31,7 \%)$ was the most common complaint. Additionally, gagging $(9,5 \%)$, dysphagia $(4,8 \%)$, pain $(4,8 \%)$, nausea $(1,6 \%)$ and throat irritation $(1,6 \%)$ were the other symptoms reported [8].

Grossly, osseous choristomas are usually under one $\mathrm{cm}$ in size, pedunculated or sessile, well-demarcated, firm, smooth surfaced, gray-white, pink colored nodular lesions [9]. 67,2\% of the osseous choristomas reported in the literature are pedunculated and $32,8 \%$ are sessile. The size of the lesion ranged from 2 to $20 \mathrm{~mm}$ and the mean size was $8,7+3,6 \mathrm{~mm}$. In our case the patient was complaining of a lump and physical examination revealed a six mm sessile lesion.

Histopathologically, lingual osseous choristoma is submucosally located and consist of well-developed lamellar bone and Haversian system. Osteoblastic and osteoclastic activity, cytological atypia or mitosis are not observed in the bone tissue [10].

Differential diagnosis of lingual osseous choristomas should be made according to where the lesion is located on the tongue. For a lesion that is situated on posterior one-third of the tongue, lingual thyroid, thyroglossal ductus cyst, mucocele, pyogenic granuloma, hemangioma, lymphangioma, hamartoma, salivary gland tumors and sarcomas should be included in the differential diagnosis. Anterior and lateral localization should be differentiated from fibroma, granular cell tumor and neural origin tumors. Salivary gland tumors, mucus retention cysts, neural tumors and lipomas are differential diagnosis with osseous choristomas located under the tongue [11].

The treatment of osseous choristoma is the total excision of the mass. Recurrence after excision is not expected. In the literature, recurrence of two cases of osseous choristoma has been reported [12].

In conclusion, lingual osseous choristoma is a rare benign lesion. This lesion, which can be confused with benign and malignant tumors in the oral cavity and maxillofacial region, should be considered when a clinicopathological diagnosis is made. In this review, available cases of lingual osseous choristomas were gathered and our case is presented with the literature.

\section{References}

1. Andressakis DD, Pavlakis AG, Chrysomali E, Rapidis AD. Infected lingual osseous choristoma. Report of a case and review of the literature. Med Oral Patol Oral Cir Bucal. 2008;13:E627-32.

2. Heinz MJ, Peters SM, Caruana SM, Yoon AJ. Lingual Osseous Choristoma of the Tongue Base: Unusual Presentation of a Rare Entity. Case Rep Otolaryngol. 2017;2017:3234086.

3. Krolls SO, Jacoway JR, Alexander WN. Osseous Choristomas (Osteomas) of intra oral soft tissues. Oral Surg. 1971;32:58895.

4. Lin C, Chen C, Shen Y, Lin L. Osseous Choristoma of Oral Cavity. Kaohsiung J Med Sci. 1998;14:727-33.

5. Cabbabe EB, Sotelo-Avila C, Moloney ST, Makhlouf MV. Osseous choristoma of the tongue. Ann Plast Surg. 1986;16:150-2.

6. Valle VE, Cheng HC, Chen YW, Lui MT, Lo WL. Osseous Choristoma of the Tongue - A Case Report. Taiwan J Oral Maxillofac Surg. 2015;26:287-92.

7. Gorini E, Mullace M, Migliorini L, Mevio E. Osseous choristoma of the tongue: a review of etiopathogenesis. Case Rep Otolaryngol. 2014;2014:373104.

8. Yamamoto M, Migita M, Ogane S, Narita M, Yamamoto N, Takaki $\mathrm{T}$ et al. Osseous choristoma in child with strong vomiting reflex. Bull Tokyo Dent Coll. 2014;55:207-15.

9. Turan Ş, Pınarbaşlı MÖ, Açıkalın M, Kaya E, Özüdoğru E. Lingual Osseous Choristoma. Turk Arch Otorhinolaryngol. 2016;54:86-8.

10. Yoshimura H, Ohba S, Imamura Y, Sano K. Osseous choristoma of the tongue: A case report with dermoscopic study. Mol Clin Oncol. 2018;8:242-5.

11. Tohill MJ, Green JG, Cohen DM. Intraoral osseous and cartilaginous choristomas: report of three cases and review of the literature. Oral Surg Oral Med Oral Pathol. 1987;63:506-10.

12. Adhikari BR, Sato J, Morikawa T, Obara-Itoh J, Utsunomiya M, Harada F et al. Osseous choristoma of the tongue: two case reports. J Med Case Rep. 2016;10:59.

13. De Rezende ARP, Leite AFSDA, Alves ATNN, De Oliveira SP, Costa RC, Lourenco SDQC. Lingual Osseous Choristoma: Report Of Case In A Child. Oral Surg, Oral Med, Oral Pathol and Oral Radiol. 2017;124,e104.

14. Tran DD, Reckley LK, Roofe SB. Asymptomatic Dorsal Tongue Mass. JAMA Otolaryngol Head Neck Surg. 2016;142:705-6.

15. Davidson S, Steiner M, Nowicki M. Lingual osseous choristoma. J Pediatr. 2016;168:247-e1.

16. Ginat DT, Portugal L. Lingual osseous choristoma. Ear Nose Throat J. 2016;95:260-1.

17. Saniasiaya J, Mohamad I, Abdul Ghani M, Ling HH. Lingual choristoma. Brunei Int Med J. 2015;11:319-21.

18. Tachasuttirut K, Omura K. Osseous Choristoma of the Tongue: Report of a Case and Review of Literature. CM Dent J. 2015;36:83-8.

19. Kaplan I, Allon I, Shlomi B, Raiser V, Allon DM. A comparative study of oral hamartoma and choristoma. J Interdiscipl Histopathol. 2015;3:129-34. 
20. Stanford JK 2nd, Spencer JC, Reed JM. Case presentation and images of a lingual osseous choristoma in a pediatric patient. Am J Otolaryngol. 2015;36:753-4.

21. Lin YZ, Hung CH, Hung SH. Lingual osseous choristoma. J Dent Sci. 2013;8:94-5.

22. Chen MH, Huang SH, Wang PC, Lin JC. Osseous choristoma of the tongue base. Fu-Jen J Med 2012;10:107-9.

23. Toda K, Watanabe Y, Komazawa D, Takegoshi H. A Case Of Osseous Choristoma On The Dorsum Of The Tongue. Jibi Inkoka Rinsho. 2012;105:647-52.

24. Kobori Y, Izumiyama Y, Suzuki T, Kitamura T, Shindoh M, Tei K. A Case Of Osseous Choristoma On The Radix Of The Tongue. Nihon Kokuka Gakkai Zasshi. 2011;60:259-63.

25. Hironaka S, Watanabe H, Nakai S, Hisa Y. A Case Of Osseous Choristoma On The Tongue Radix. Jibi Inkoka Rinsho. 2010;103:725-8.

26. Naik VR, Wan Faiziah W, Musa MY. Choristoma of the base of the tongue. Indian J Pathol Microbiol. 2009;52:86-7.

27. Hibi Y, Ohno A, Sasabe E, Ueta E, Yamamoto T. A case of lingual osseous choristoma. Nihon Koku Geka Gakkai Zasshi. 2007;53:233-7.

28. Benamer MH, Elmangoush AM. Lingual osseous choristoma case report and review of literature. Libyan J Med. 2007;2:46-8

29. Velez I, Mintz S. Gigantiform choristoma of the lateral tongue. The report of a rare case and discussion of the literature. Todays FDA. 2003;15:18-9.

30. Horn C, Thaker HM, Tampakopoulou DA, De Serres LM, Keller JL, Haddad J Jr. Tongue lesions in the pediatric population. Otolaryngol Head Neck Surg. 2001;124:164-9.

31. PiattelliA, Fioroni M, Orsini G, Rubini C. Osteochondromatous choristoma of the tongue: report of a case. J Oral Maxillofac Surg. 2000;58:1320-2.

32. Supiyaphun P, Sampatanukul P, Aeumjaturapat S, Kerekhanjanarong V, Sastarasadhit V. Lingual osseous choristoma: report of three cases. J Med Assoc Thai. 2000;83:564-8.

33. Kim YS, Park MK, Park CK. A Case of Lingual Osseous Choristoma. Korean J Otolaryngol-Head Neck Surg. 1999;42:255-7.

34. Supiyaphun P, Sampatanakul P, Kerekhanjanarong V, Chawakitchareon P, Sastarasadhit V. Lingual osseous choristoma: a study of eight cases and review of the literature. Ear, Nose and Throat J. 1998;77:316-25.

35. Vered M, Lustig JP, Buchner A. Lingual osteoma: a debatable entity. J Oral Maxillofac Surg. 1998;56:9-14.

36. Horie N, Shimoyama T, Ida F. Lingual osseous choristoma in the early stage of maturation. Oral Medicine and Pathology. 1998;3:49-50.

37. Pineau A, Billet J, Auffrey N, Piot B, Mercier J. Lingual osteoma. Apropos of a case. Rev Stomatol Chir Maxillofac. 1997;98:243-5.

38. Nakanishi Y, Oomata T, Morita N, Wada T, Inbe H, Sakamoto T. A case of osseous choristoma near the foramen caecum of the tongue. Nihon Koku Geka Gakkai Zasshi. 1996;42:7057.

39. Manganaro AM. Lingual osseous choristoma. Gen Dent. 1996;44:430-1.

40. Ngeow WC, Lian CB, Shanmahasuntharam P. Osseous choristoma of the tongue. The J Nihon Univ Sch Dent. 1996;38:49-51.

41. Takahashi Y, Kawano K, Hirano K, Yanagisawa S, Kyougoku J. A case of osseous choristoma on the posterior dorsum of the tongue. Nihon Koku Geka Gakkai Zasshi. 1995;41:42931.

42. Wang JT, Chiang CP, Kuo YS, Liu BU, Lin SK, Chen CC et al. Osseous choristoma of the tongue: report of a case and review of the literature. Chin J Oral Maxillofac Surg. 1993;4:10-7.

43. Nozoe E, Mimura T, Sonoda A, Miyawaki A, Semba I, Kitano M. A case of osseous choristoma on the tongue. Nihon Koku Geka Gakkai Zasshi. 1993;39:940-2.

44. Ishikawa M, Mizukoshi T, Notani K, Iizuka T, Amemiya A, Fukuda H. Osseous choristoma of the tongue: report of two cases. Oral Surg Oral Med Oral Pathol. 1993;76:561-3.

45. Machino M, Yamaguchi H, Osawa K, Otono T, Masuda T, Utsumi N. A case of lingual osseous choristoma. Nihon Koku Geka Gakkai Zasshi. 1990;36:1851-5.

46. Shintani Y, Yoshikawa K, Kuwazawa T, Sangu Y, Ogiuchi $\mathrm{H}$. A case of lingual osseous choristoma. Nihon Koku Geka Gakkai Zasshi. 1990;36:1343-7.

47. Mizukami R, Asada K, Nakagawa Y, Yamamoto H, Ishibashi $\mathrm{K}$. A case of lingual osseous choristoma. Nihon Koku Geka Gakkai Zasshi. 1988;34:2009-11.

48. Ioroi K, Matsumoto M, Kobayashi C, Maekawa K, Fukuzaki $\mathrm{H}$, Fukutake $\mathrm{K}$ et al. A case of osseous choristoma near the foramen caecum of the tongue. Japanese Journal of Oral \& Maxillofacial Surgery. 1986;32:1057-60.

49. Weitzner S. Osseous choristoma of the tongue. South Med J. 1986;79:69-70.

50. Shimono M, Tsuji T, Iguchi Y, Yamamura T, Ogasawara $\mathrm{M}$, Honda $\mathrm{T}$ et al. Lingual osseous choristoma. Report of 2 cases. Int J Oral Surg. 1984;13:355-9.

51. Azuma T, Koike M, Komori A, Yanagawa T, Sato M. Osseous choristoma of the tongue: report of a case. Nihon Koku Geka Gakkai Zasshi. 1984;30:156-9.

52. Sheridan SM. Osseous choristoma: a report of two cases. $\mathrm{Br}$ J Oral Maxillofac Surg. 1984;22:99-102.

53. McClendon EH. Lingual osseous choristoma: report of two cases. Oral Surg Oral Med Oral Pathol. 1975;39:39-44.

\section{(i) (8)}

This work is licensed under a Creative Commons AttributionNon Commercial 4.0 International License. 